\title{
Optimization of in vitro culture conditions for obtaining flax (Linum usitatissimum L. cv. Modran) cell suspension culture
}

\author{
Aleksandra Seta-Koselska*, Ewa SKóRZYŃSKa-Polit \\ Department of Plant Physiology and Biotechnology, Institute of Biotechnology, \\ The John Paul II Catholic University of Lublin, Lublin, Poland
}

\begin{abstract}
Flax (Linum usitatissimum L.) is an ancient crop that is widely cultivated as a source of oil, fiber, and bioactive compounds. Flax fiber is traditionally used in textile industry, linseed oil is processed for industrial oils, paints, varnishes and bio-petroleum. Flaxseeds are also rich in $\alpha$-linolenic acid and phytochemicals such as lignans. In addition to the commercial aspects, this species has been used widely and readily in biotechnological, developmental, and plant-pathogen interaction studies. Differences in the levels of endogenous hormones in various cultivars of flax significantly affected the intensity of callogenesis and determined the type and concentration of growth regulators necessary for callus production. The aim of our investigation was to optimize the culture conditions for callus formation and cell proliferation in liquid medium of the Polish cultivar of fiber flax - Modran. In the first step, 4 combinations of phytohormones in the medium were tested to obtain established callus tissue suitable for initiation of suspension culture. Next, we investigated the effect of chosen plant growth regulators on cell divisions, fresh and dry weight, and dispersal of callus cells in liquid medium. Fast growing and friable callus was obtained in a modified MS medium supplemented with $0.5 \mathrm{mg} / 1 \mathrm{BAP}$ and $0.1 \mathrm{mg} / \mathrm{l} \mathrm{NAA}$. We determined that for the initiation of cell suspension supplementation with $0.5 \mathrm{mg} / \mathrm{l} \mathrm{BAP}$ and $0.5 \mathrm{mg} / \mathrm{l} \mathrm{NAA}$ is optimal. The results obtained indicated that high concentration of cytokinin (BAP) in liquid medium limited cell proliferation and decreased biomass formation.
\end{abstract}

Key words: Linum usitatissimum, callus culture, cell suspension culture

\section{Introduction}

Linum usitatissimum L. has a long history of traditional use as a source of both oil and fiber. Two types of L. usitatissimum used commercially are flax, grown for fiber, and linseed, grown for seed. Flax fiber is traditionally used in textile industry; and flax or linseed tow is used in furniture and building industries and as a substitution of plastic components in the automotive and aircraft industries (Barkoula et al., 2010). Flaxseed oil is an excellent source of omega-3 fatty acids, that is, linolenic acid, while linseed oil is processed for industrial oils, paints, varnishes, and biopetroleum. According to Broadley et al. (2001), flax is considered as a Cd-accumulator species, and may have a role in successive decontamination of agricultural soils polluted by heavy metals (Bjelkova et al., 2011).
Flaxseed is consumed by humans as a functional food due to an increasing demand of edible oil sources of omega-3 fatty acids, and is also added to animal feed to improve their reproductive performance and health (Malik et al., 2014). Moreover, flaxseed is also rich in various phytochemicals such as lignans. Water- and alcohol-soluble (+)-secoisolariciresinol diglucoside (SDG) is the main lignan found in flaxseed. SDG is converted to mammalian lignans, such as enterodiol (END) and enterolactone (ENL), by intestinal bacteria. These mammalian lignans exhibit antioxidant activities and are suggested to play a role in the reduction of hypercholesterolemia, atherosclerosis, and diabetes (Prasad, 2000). The hypoglycemic potential of flaxseed largely depends on the inhibitory capacities of SDG toward pancreatic $\alpha$-amylase (Hano et al., 2013). Szewczyk and coworkers

\footnotetext{
* Corresponding author: Department of Plant Physiology and Biotechnology, Institute of Biotechnology, The John Paul II Catholic University of Lublin, Konstantynów 1I, 20-708 Lublin, Poland; e-mail: bionix@kul.lublin.pl
} 
(2014) demonstrated that a highly concentrated extract from $L$. usitatissimum resulted in a significant increase in apoptosis in human breast cancer cell lines. Due to its potential health benefits, flaxseed is the focus of increased interest in diseases and diet research fields.

In addition to the commercial uses described earlier, this species has been widely and readily used in biotechnological, developmental, and plant-pathogen interaction studies. L. usitatissimum has a long history of in vitro culture applications, for example, flax embryos were one of the first in vitro cultivated embryos. Later on, Millam et al. (2005) reported flax's ability to initiate buds from hypocotyls and indicated applications of the in vitro system based on flax tissue cultures to study plantpathogen interactions. Ibrahim (1971) conducted the study of the improvement and optimization of the culture medium for flax cultivation. Ling and Binding (1987) were the first to isolate the protoplast from flax tissues. Flax protoplasts are widely used in biochemical and physiological studies, especially on the composition and formation of the cell wall or transformation (Gamborg and Shyluk, 1976; David et al., 1995; Ling and Binding, 1997). In vitro cultivation of cells and tissues can lead to somaclonal variation, which depends on the type of tissue from which the cells are derived, the duration of the culture, and the combination of exogenous factors (e.g., plant growth regulators). Somaclonal variation causes genetic instability, but may also result in favorable features appearing in regenerates; for example, a new line of flax with an increased resistance to Fusarium oxysporum is obtained (Rutkowska-Krause et al., 2003). Anther culture and microspore regeneration system in flax are useful tools for molecular marker studies and for production of haploid and doubled haploid lines (Millam et al., 2005). Flax is one of the first crops successfully transformed with Agrobacterium. Jordan and McHughen (1988) reported the first flax transformation via Agrobacterium, while the first transgenic flax plants obtained via particle bombardment were studied by Wijayanto and McHughen (1999) L. usitatissimum is therefore a valuable tool for both the basic and applied studies.

Behar and coworkers (2011) demonstrated that the differences in the levels of endogenous hormones in various cultivars of flax significantly affected the intensity of callogenesis and also determined the types and con- centrations of growth regulators necessary for callus production. Our investigation was therefore aimed to optimize the culture conditions for callus formation and cell proliferation in a liquid medium of a Polish cultivar of fiber flax - Modran. Its genotype was obtained by crossing Ariane and Smoleński cultivars. Modran revealed high resistance to Fusarium and a very high resistance to lodging. It is also one of the cultivars with the highest quality of fiber (Heller, 2012).

Four combinations of phytohormones in the medium were chosen and tested to obtain an established callus tissue suitable for initiation of suspension culture in the first step. Next, the effects of the chosen plant growth regulators on cell divisions, fresh weight (FW) and dry weight (DW), and dispersing callus cells in a liquid medium were investigated. The cell suspension culture is applied in the biochemical, molecular, and physiological research, as well as in the commercial plant biotechnology.

\section{Materials and methods}

\section{Plant material}

L. usitatissiumum seeds of the cultivar Modran used in the experiments were obtained from the Institute of Natural Fibers and Medicinal Plants, Poznan, Poland. Modran is one of the latest cultivars bred in the Experimental Station, Petkowo (registered in 2001). The plant material used in the study was obtained from a nonsterile culture. Seeds were sown into sterilized soil and grown in darkness in a breeding room at $24^{\circ} \mathrm{C}$ for 1 week.

\section{Establishment of a callus culture}

Seedlings were harvested after 7 days of cultivation, rinsed in $75 \%$ ethanol for $30 \mathrm{~s}$, surface sterilized with 7\% commercial bleach containing $4.8 \%$ sodium hypochlorite, and washed 4 times with sterile distilled water. About 10-15 mm long hypocotyl segments were excised and cultured in Petri dishes on a modified MS medium ( $2 \mathrm{mg} / 1$ nicotinic acid; $2 \mathrm{mg} / 1$ pyridoxine) (Murashige and Skoog, 1962), supplemented with 3\% (w/v) sucrose as a carbon source and solidified with $0.8 \%$ agar. The $\mathrm{pH}$ of the medium was adjusted to 5.6-5.8 before autoclaving. To obtain appropriate condition for callogenesis, four variants of plant hormone combinations were added to the basal culture medium and tested: 1) $0.5 \mathrm{mg} / 1$ 
6-benzylaminopurine (BAP) and $0.05 \mathrm{mg} / 1$ 1-naphthaleneacetic acid (NAA); 2) $0.5 \mathrm{mg} / 1 \mathrm{BAP}$ and $0.5 \mathrm{mg} / \mathrm{l}$ 3-indoleacetic acid (IAA); 3) $1 \mathrm{mg} / \mathrm{l}$ kinetin (KIN) and $0.5 \mathrm{mg} / \mathrm{l} \mathrm{IAA}$; 4$) 0.5 \mathrm{mg} / \mathrm{l} \mathrm{BAP}$ and $0.1 \mathrm{mg} / \mathrm{l} \mathrm{NAA}$. Callus cultures were inducted in 120-mm Petri dishes, each containing $60 \mathrm{ml}$ of the tested medium and 12 hypocotyl explants. A minimum of 96 explants were tested for each combination of plant growth regulators. After 8 weeks of culture, the callus tissue was transferred to $150-\mathrm{mm}$ Petri dishes. The cultures were incubated in phytotron in darkness at $24^{\circ} \mathrm{C}$ and subcultured to a fresh medium every 4 weeks. Any organs formed were removed during the transfer to fresh media. The most suitable calli for the initiation of suspension cultures were chosen after 6 months of culture.

\section{Initiation of a cell suspension culture}

The callus tissues obtained on the solid modified MS medium supplemented with $0.5 \mathrm{mg} / \mathrm{l} \mathrm{BAP}$ and $0.1 \mathrm{mg} / \mathrm{l}$ NAA were used for obtaining the cell suspension cultures. To initiate the cultures, $5 \mathrm{~g}$ undifferentiated, friable callus tissue was comminuted and transferred to a $250 \mathrm{ml}$ Erlenmeyer flask containing $100 \mathrm{ml}$ of the liquid medium. The basal medium was composed of halfstrength microelements, unmodified microelements, and slightly modified organic compounds $(2 \mathrm{mg} / 1$ nicotinic acid; $2 \mathrm{mg} / \mathrm{l}$ pyridoxine) of the MS medium. To determine the appropriate conditions for the induction of flax cell suspension cultures, two combinations of phytohormones were tested: 1) $2 \mathrm{mg} / \mathrm{l} \mathrm{BAP}$ and $0.5 \mathrm{mg} / \mathrm{l} \mathrm{NAA}$ and 2) $0.5 \mathrm{mg} / \mathrm{l} \mathrm{BAP}$ and $0.5 \mathrm{mg} / 1 \mathrm{NAA}$. A total of 20 flasks were tested for each combination of plant hormones. All suspensions were incubated on an orbital shaker at $120 \mathrm{rpm}$ in the dark at $24^{\circ} \mathrm{C}$ and subcultured every 14 days. Cultures were conducted for 220 days.

\section{Determination of the parameters of the cell suspension culture}

The growth of cell suspensions during a 14-day cycle was determined by the measurements of FW. Cells and aggregates were drained in a sterile sieve with autoclaved standard qualitative filter papers and weighted in aseptic conditions on the $3^{\text {rd }}, 5^{\text {th }}, 7^{\text {th }}, 10^{\text {th }}, 12^{\text {th }}$, and $14^{\text {th }}$ days of culture. On the $14^{\text {th }}$ day of culture, DW was determined after drying at $70^{\circ} \mathrm{C}$. The increase in $\mathrm{FWs}$ and DWs was assessed in 10 flasks for each combination of plant hormones.

\section{Results}

The most frequently applied sources of cells for the initiation of suspensions are the established callus cultures, consisting undifferentiated and loosely joined cells. To obtain these calli, cultures should be maintained for about 6 months. The growth and proliferation of callus tissues heavily depends on the external supply of plant hormones in the synthetic media.

After 16 days of culture on the medium supplemented with $0.5 \mathrm{mg} / 1 \mathrm{BAP}$ and $0.05 \mathrm{mg} / 1 \mathrm{NAA}$ (variant 1 ), approximately $90 \%$ of the hypocotyl explants formed callus tissues along the entire length. The calli were usually yellow and friable, sometimes white with a compact structure, and the formation of shoots was observed (Fig. 1A). After 28 days of culture, the rate of callus formation was high whereas shoot organogenesis was also observed (Fig. 1B). The appearance of organogenesis was considered as negative and unintended effect; therefore, a new variant (4) of a phytohormone combination was introduced $(0.5 \mathrm{mg} / 1 \mathrm{BAP}$ and $0.1 \mathrm{mg} / \mathrm{l} \mathrm{NAA})$. During the next 4 weeks, callogenesis and rhizogenesis were observed in variant 1 . As shown in Figure 1C, usually white and compacted calli formed shoots, whereas roots were formed in a smaller number and mostly on the yellow calli. After 120 days of culture, the callus tissues became more homogenous (yellow and friable) and no organogenesis was observed (Fig. 1D). After 16 days of culture on a medium containing $0.5 \mathrm{mg} / 1 \mathrm{BAP}$ and $0.5 \mathrm{mg} / \mathrm{l} \mathrm{IAA}$ (variant 2), slightly more than $50 \%$ of the explants formed calli with heterogeneous structures (Fig. 1E). During the next 2 weeks, the rate of callus formation increased; some of the hypocotyls were covered with yellow and friable callus tissues and others with compacted and hard white or brown calli (Fig. 1F). The presence of roots on the explants was rarely reported. The frequency of callus formation was relatively low in this variant; furthermore, the calli were nonhomogenous meaning that yellow, white, and brown calli occurred within one explant (Fig. 1G, Fig. 1H). After 16 days of culture on the medium supplemented with $1 \mathrm{mg} / \mathrm{l} \mathrm{KIN}$ and $0.5 \mathrm{mg} / \mathrm{l} \mathrm{IAA}$ (variant 3 ), $70 \%$ of the hypocotyls were swollen along the entire length, and only a few produced calli at the injury site (Fig. 1I). Prior to the first passage onto the fresh medium, root organogenesis was detected (Fig. 1J). The calli were yellow and friable, as well as white and tough. After 2 months of cultivation, rhizo- 


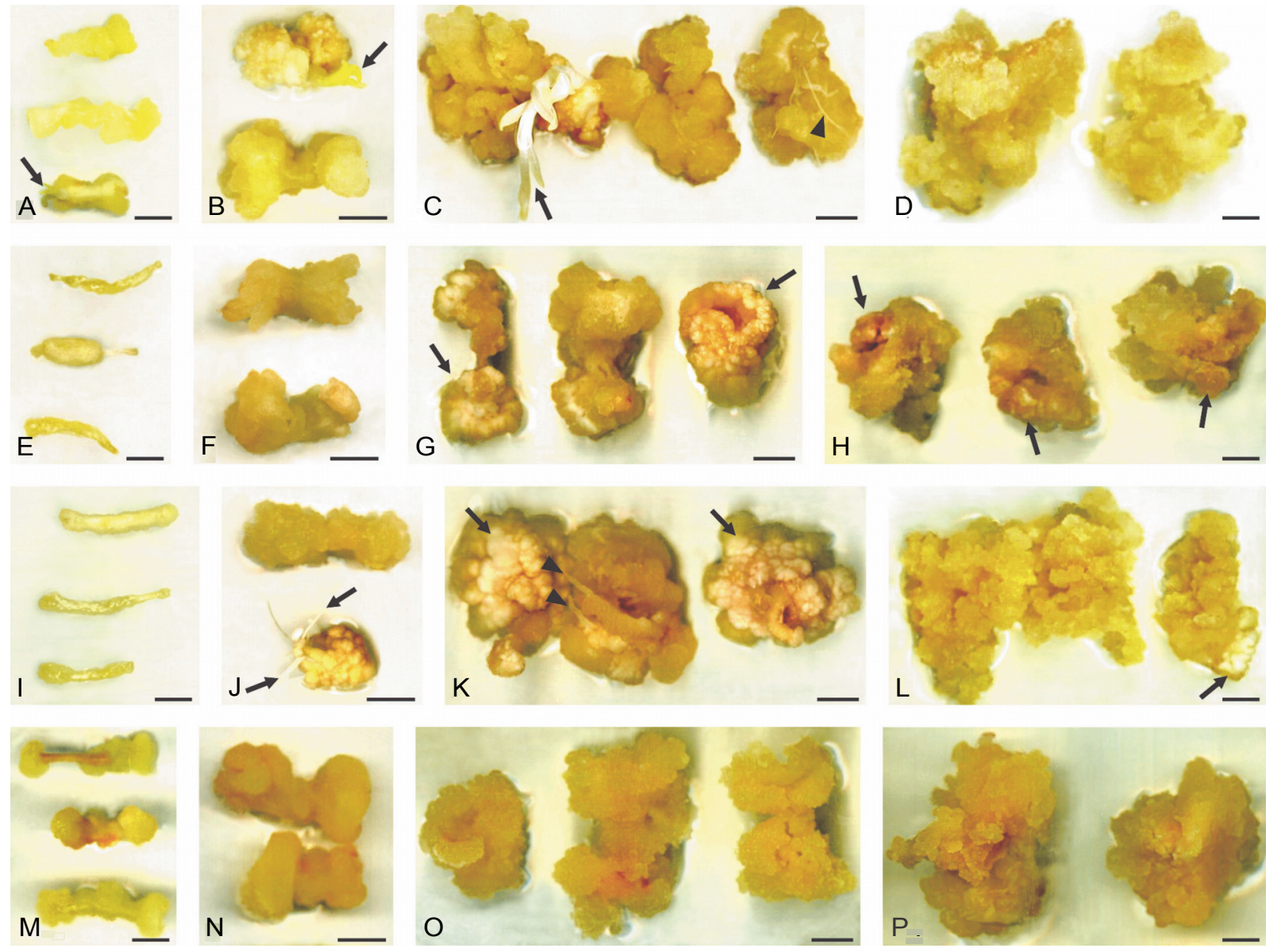

Fig. 1. Comparison of callus tissue formation on a solid medium supplemented with $0.5 \mathrm{mg} / 1 \mathrm{BAP}$ and $0.05 \mathrm{mg} / 1 \mathrm{NAA}$ (A-D), $0.5 \mathrm{mg} / 1 \mathrm{BAP}$ and $0.5 \mathrm{mg} / \mathrm{l} \mathrm{IAA}(\mathrm{E}-\mathrm{H}), 1 \mathrm{mg} / 1 \mathrm{KIN}$ and $0.5 \mathrm{mg} / \mathrm{lAA}$ (I-L), $0.5 \mathrm{mg} / 1 \mathrm{BAP}$ and $0.1 \mathrm{mg} / 1 \mathrm{NAA}$ (M-P). Bar indicates $5 \mathrm{~mm}$. A) Hypocotyls after 16 days of culture with a primordium of a shoot (arrow); B) Hypocotyls after 28 days of culture with a shoot (arrow); C) Callus tissue after 56 days of culture, a visible shoot (arrow) and root (arrowhead); D) Relatively homogenous callus tissue after 120 days of culture; E) Hypocotyls after 16 days of culture with relatively low callus growth; F) Hypocotyls after 28 days of culture covered with a heterogeneous callus tissue; G) Callus tissue after 56 days of culture with insertions of white and tough fragments (arrows); H) Non-homogenous callus tissue after 120 days of culture with brown, compacted fragments (arrows); I) Hypocotyls after 16 days of culture, low callus growth; J) Hypocotyls after 28 days of culture, some explants covered with white and hard callus tissue, visible rhizogenesis (arrows); K) Callus tissue after 56 days of culture with numerous inserts of white and hard fragments (arrows), visible roots (arrowheads); L) Callus tissue after 120 days of culture, visible white inclusions (arrow); M) Hypocotyls after 16 days of culture with a relatively high callus growth especially at the injury site; N) Hypocotyls after 28 days of culture; O) Calli after 56 days of culture consisting of yellow and friable tissue; P) Homogenous callus tissue after 120 days of culture

genesis still proceeded (Fig. 1K). After 120 days, the callus tissues were almost homogenous with minor insertions of white tissues (Fig. 1L). After 16 days, a majority of the explants (about 90\%) in variant 4 were overgrown with yellow and friable calli (Fig. 1M), and after 28 days no organogenesis was observed (Fig. $1 \mathrm{~N}$ ). The rate of callus formation was the highest in this variant. After 2 months, the callus was rather homogenous (Fig. 10), with a few insertions of white and brown tissues. The structure of the callus tissue after 120 days of culture was adequate for the induction of the cell suspension. The calli were friable, homogenous in structure, and facile to fragmentation (Fig. 1P). We obtained a fast-growing and friable callus in the modified MS medium supplemented with $0.5 \mathrm{mg} / \mathrm{l} \mathrm{BAP}$ and $0.1 \mathrm{mg} / 1 \mathrm{NAA}$; therefore, we recommend this combination of plant hormones to be used to achieve an appropriate callus tissue for initiation of cell suspension of fiber flax cultivar Modran. 

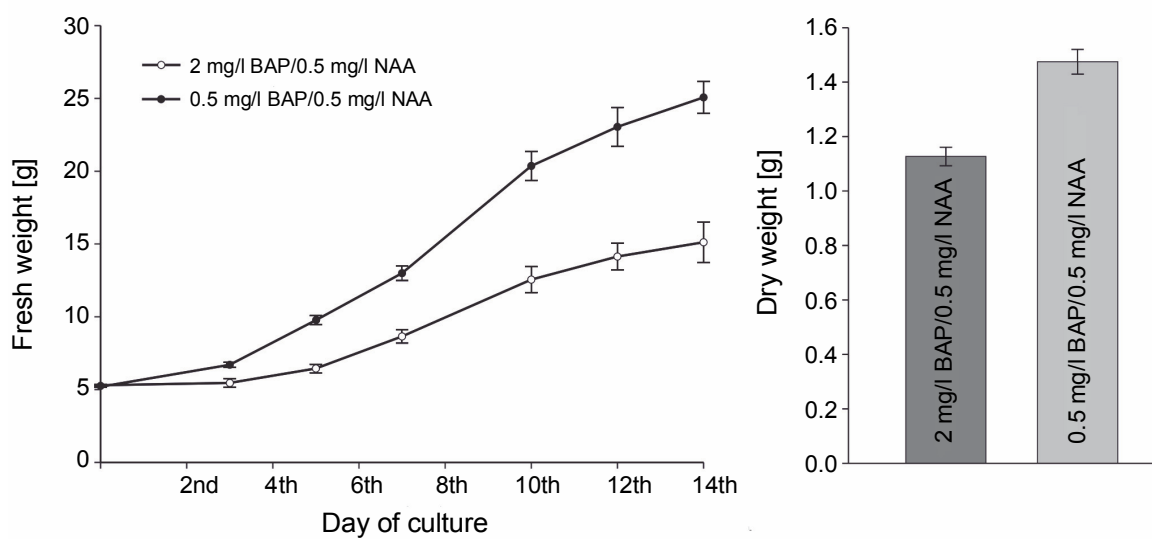

A

B

Fig. 2. A) Changes in callus fresh weight during the 14-day cycle and B) the amount of dry weight after the 14-day cycle

The composition of a liquid medium is another crucial factor affecting the efficiency of initiation of cell suspension cultures. In a study on the accumulation of lignins and lignans in a flax suspension, Hano and coworkers (2006) used an MS medium supplemented with $2 \mathrm{mg} / \mathrm{l} \mathrm{BAP}$ and $0.5 \mathrm{mg} / \mathrm{l} \mathrm{NAA}$. Therefore we decided to check whether this combination of plant hormones (variant 1) was suitable for obtaining a high frequency of cell proliferation and biomass production of Modran. We also examined the effects of equal amounts of cytokinin and auxin $(0.5 \mathrm{mg} / 1 \mathrm{BAP}$ and $0.5 \mathrm{mg} / \mathrm{l} \mathrm{NAA})$ on the growth parameters of the suspension (variant 2) in a liquid medium.

A higher increase in FW was observed in the variant 2 (Fig. $2 \mathrm{~A}$ ). In this case, the growth rate was high during the first few days after transfer (lack of a lag phase), and the FW doubled after 5 days of the cultivation. The highest increase in biomass was detected between the 7 th and 10th days of culture in both variants. The gain of DW was lower in the variant 1 (Fig. 2B). The obtained results indicated that high concentrations of cytokinin (BAP) in the liquid medium limited the cell proliferation and diminished the biomass formation.

The suspensions were conducted for 220 days to examine the stability of the cultures. Spontaneous changes in the structure of the cell aggregates were recorded. The callus tissue turned brown and was compacted, the growth rate decreased, and finally all the changed suspensions died in about $15 \%$ flasks from both variants. This effect was not correlated with the duration of the culture. While the suspension looked homogenous and consisted of cells and cell aggregates in $85 \%$ of flasks.

\section{Discussion}

In the previous studies on flax in vitro cultures, hypocotyls were usually used as a source of explants, and their capability for shoot formation and somatic embryogenesis was established. Janowicz and Wojciechowski (2009) confirmed that hypocotyl explants had the highest morphogenetic potential. Our research demonstrates that hypocotyl explants of flax Modran cv. are appropriate for the induction of callus formation, and when properly selected, a combination of plant hormones blocks the natural organogenesis capability of hypocotyls. Among plant hormones, auxins and cytokinins appear to be the most effective in promoting callus formation. Belonogova and Raldugina (2006) showed a high frequency of callogenesis in cotyledon explants on a medium supplemented with auxin (NAA). Moreover, Janowicz and Wojciechowski (2009) showed that hypocotyl explants of Modran were the most effective in callus tissue formation on an MS medium supplemented with NAA. Burbulis and coworkers (2005) demonstrated that an addition of cytokinin had a positive effect on shoot regeneration from callus. Similar results were obtained by Salaj and coworkers (2005) for hypocotyl explants. The morphogenetic potential of the callus tissue was observed on a medium supplemented with cytokinin, whereas a non-morphogenic callus occurred on a medium amended only with auxin (Salaj et al., 2005). Our results have confirmed these previous reports. Among the tested combinations of plant growth regulators, the highest frequency of callus formation occurred on a medium supplemented with BAP and NAA; moreover, the 
stimulatory effect of cytokinins on shoot formation might be abolished by auxin supplementation. Mundhara and Rashid (2002) postulated that to some extent shoot organogenesis on hypocotyls was determined by the content of cytokinins in the medium, but depended on the light conditions. We have demonstrated that shoot formation on hypocotyls occurred in darkness and the shoots formed were etiolated.

We have found that a higher concentration of cytokinin in a liquid medium had an inhibitory effect on cell proliferation and biomass formation. This observation confirmed the report of $Z$ han and coworkers (1989), who stated that a too high concentration of cytokinin in the medium inhibited regeneration and precluded formation of the callus. The results of our studies indicate that an appropriate balance between the amount of auxin and cytokinin in the medium promotes cell proliferation and increases biomass production in suspension cultures.

\section{References}

Barkoula N.M., Garkhail S.K., Peijs T. (2010) Biodegradable composites based on flax/polyhydroxybutyrate and its copolymer with hydroxyvalerate. Ind. Crops Prod. 31: 34-42.

Behar N., Kumar P., Chandel G. (2011) Effect of explant type, genotype and plant growth regulators on morphogenetic potential of flax (Linum usitatissimum L.). J. Cell Plant Sci. 2: 13-18.

Belonogova M.A., Raldugina G.N. (2006) Shoot regeneration from cotyledon explants of fiber flax (Linum usitatissimum) and their subsequent rooting. Russ. J. Plant Phys. 53: 501-506.

Bjelkova M., Gencurova V., Griga M. (2011) Accumulation of cadmium by flax and linseed cultivars in field stimulated conditions: a potential for phytoremediation of Cd-contaminated soils. Ind. Crops Prod. 33: 761-774.

Broadley M.R., Willey N.J., Wilkins J.C., Baker A.J.M., Mead A., White P.J. (2001) Phylogenetic variation in heavy metal accumulation in angiosperms. New Phytol. 152: 9-27.

Burbulis N., Blinstrubiene A., Venskutoniene E., Katauskyte L. (2005) Organogenesis in callus cultures of Linum usitatissimum L. Acta Univ. Latv. 691: 129-135.

David H., Bade P., David A., Savy C., Demazy C., Van Cutsem P. (1995) Pectins in walls of protoplast-derived cells im bedded in agarose and alginate beads. Protoplasma 186: 122-130.

Gamborg O.L., Shyluk J.P. (1976) Tissue culture, protoplasts and morphogenesis in flax. Bot. Gaz. 137: 301-306.

Hano C., Addi M., Bensaddek L., Crônier D., Baltora-Rosset S., Doussot J. et al. (2006) Differential accumulation of monolignol-derived compounds in elicited flax (Linum usitatissimum) cell suspension cultures. Planta 223: 975-989.
Hano C., Renouard S., Molinié R., Corbin C., Barakzoy E., Doussot J. et al. (2013) Flaxseed (Linum usitatissimum L.) extract as well as (+)-secoisolariciresinol diglucoside and its mammalian derivatives are potent inhibitors of $\alpha$-amylase activity. Bioorg. Med. Chem. Lett. 23: 3007-3012.

Heller K. (2012) Metodyka integrowanej ochrony roślin dla uprawy lnu włóknistego. Methodology of integrated plant protection for the cultivation of fibrous flax. https://www. minrol.gov.pl/content/download/38414/213340/version/2/

Ibrahim R.K. (1971) Media for growth of flax tissue culture. Can. J. Bot. 49: 295-298.

Janowicz J., Wojciechowski A. (2009) The evaluation of regeneration ability of two flax (Linum usitatissimum L.) cultivars in in vitro culture. Oilseed Crops. 30: 35-50.

Jordan M.C., McHughen A. (1988) Glyphosate tolerant flax plants from Agrobacterium mediated gene-transfer. Plant Cell Rep. 7: 281-284.

Ling H.Q., Binding H. (1997) Transformation in protoplast cultures of Linum usitatissimum and L. suffruticosum mediated with PEG and with Agrobacterium tumefaciens. J. Plant Physiol. 151: 479-488.

Malik S., Bíba O., Grúz J., Arroo R.R.J., Strnad M. (2014) Biotechnological approaches for producing aryltetralin lignans from Linum species. Phytochem. Rev. 13: 893-913.

Millam S., Obert B., Pretová A. (2005) Plant cell and biotechnology studies in Linum usitatissimum - a review. Plant Cell Tiss. Org. 82: 93-103.

Mundhara R., Rashid A. (2002) Stimulation of shoot-bud regeneration on hypocotyl of Linum seedlings, on a transient withdrawal of calcium: effect of calcium, cytokinin and thidiazuron. Plant Sci. 162: 211-214.

Murashige T., Skoog F. (1962) A revised medium for rapid growth and bio assays with tobacco tissue cultures. Physiol. Plant. 15: 473-497.

Prasad K. (2000) Antioxidant activity of secoisolariciresinol diglucoside-derived metabolites, secoisolariciresinol, enterodiol, and enterolactone. Int. J. Angiol. 9: 220-225.

Rutkowska-Krause I., Mankowska G., Lukaszewicz M. (2003) Regeneration of flax (Linum usitatissimum L.) plants from anther culture and somatic tissue with increased resistance to Fusarium oxysporum. Plant Cell. Rep. 22: 110-116.

Salaj J., Petrovská B., Obert B., Pretová A. (2005) Histological study of embryo-like structures initiated from hypocotyl segments of flax (Linum usitatissimum L.). Plant Cell Rep. 24: 590-595.

Szewczyk M., Abarzua S., Schlichting A., Nebe B., Piechulla B., Briese V. et al. (2014) Effects of extracts from Linum usitatissimum on cell vitability, proliferation and cytotoxity in human breast cancer cell lines. J. Med. Plants Res. 8: 237-245.

Wijayanto T., McHughen A. (1999) Genetic transformation of Linum by particle bombardment. In Vitro Cell Dev. Biol. Plant. 35: 456-465.

Zhan X.C., Jones D.A., Kerr A. (1989) In vitro plantlet formation in Linum marginale from cotyledons, hypocotyls, leaves, roots and protoplasts. Aust. J. Plant Physiol. 16: 315-320. 